\title{
URBAN PLANNING AND ITS IMPACT ON THE CITY OF HEBRON, PALESTINE
}

\author{
WAEL SHAHEEN \\ Department of Civil and Architectural Engineering, Palestine Polytechnic University, Palestine
}

\begin{abstract}
Due to its history of more than 5,000 years, Hebron is considered one of the most ancient cities in the world. It has been occupied several times throughout history, by Romans, Byzantines, Ottomans, Mamluks, the British Mandate and finally the Israeli Occupation. All these people marked the urban planning of the town in many ways, until the present day. There is no doubt that Hebron City suffers from severe weaknesses related to urban planning, because of the failure of structural plans that aren't keeping up with the rapid development that the city has been going through for the past few years. Actually, if we took a moment to observe some Arab cities like Beirut and Amman, we would realize they're all in the same situation; all of them lack a proper, well-planned layout. On the contrary, very old cities such as Al-Basra in Iraq, had very special environmental considerations still valid nowadays, but there are other examples and models of sustainability standards within the planning of the Arab cities. However, we can still find some global obstacles facing the Arab World regarding their planning potentials. Palestine consists of many cities, Hebron is one of the biggest cities in terms of total area and population density. Unfortunately, it lacks an effective structural planning to fulfill the city's continuous unstoppable development, due to various circumstances affecting the planning process in the city, which has influenced the land use. Moreover, there is a losing control over areas inside and around the city because of the Israeli Occupation. Due to the huge importance of urban planning and the human ultimate need for it in all different sectors, this research aims to explain and clarify the definition of the space and incorporate its cultural values and characteristics. The factors affecting urban planning will be clarified, as well as explaining how to create a different reality that develops the city and preserves its heritage, history, resources and sectors.
\end{abstract}

Keywords: planning, law, rehabilitation, economy, development, tourism, culture.

\section{INTRODUCTION}

Hebron is considered one of the most important Palestinian cities, especially from a religious and historical point of view because it dates back to around 5,000 years ago [1]. Hebron Governorate contains more than 650 archaeological and historical sites, among which the site of the Tomb of the Patriarchs and the remains of ancient churches, as well as The Monastery of the Holy Trinity, located in the west of the city, highly visited by tourists from abroad. Furthermore, we find more than 170 mosques, of which more than 50 are old mosques and others are newly constructed.

Geographically, Hebron is located $36 \mathrm{~km}$ from the city of Jerusalem and Bethlehem [2].

The city center was affected after the establishment of outposts following Israeli occupation in 1967, which led to the displacement of residents from the heart of the city to outside. Most of the migration from the city center occurred after the settlers' assault on the Ibrahimi Mosque in 1994, and this affected it commercially, as all the commercial markets were in the old center, and it represented one of the greatest commercial centers in the West Bank.

Furthermore, after the signing of the Oslo Accords in 1993, the Palestinian Authority took control of part of the town and opened the door, without any planned strategy to import products from China, Turkey and elsewhere, which had a negative impact, and led to the deterioration of economic life and negatively affected most of the cities, of the entire West Bank. So, factories were closed, especially factories making shoes and clothes which were 
prosperous in the city, and life deteriorated and consequently this led to poverty. Besides, without structural plans random urbanization appeared, which was not related to the old architecture [3], as well as visual distortion, traffic congestion, and the spread of vendors in the streets and on its sidewalks because of the lack of city markets (Fig. 1).

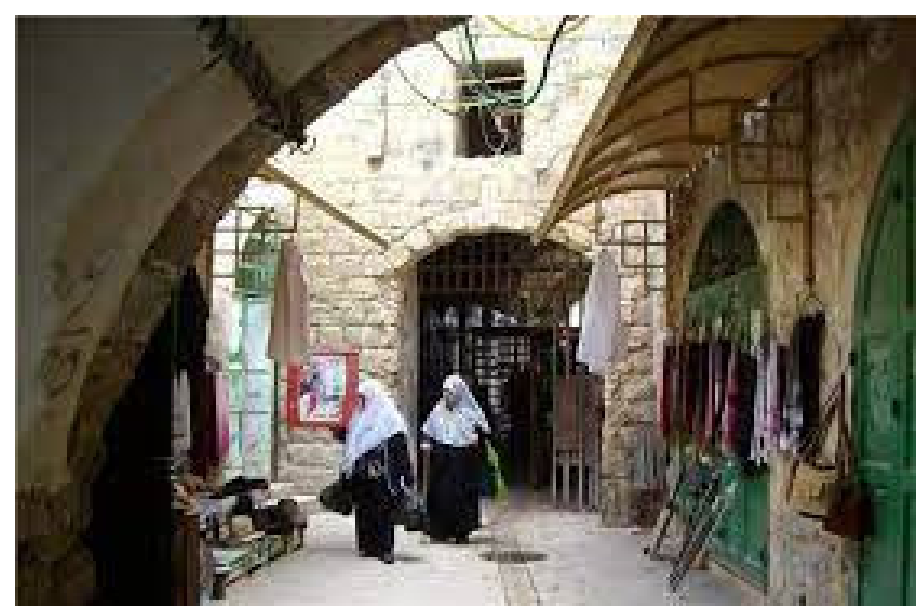

Figure 1: Inside the old city of Hebron.

The author would like to shed light on some broad outlines of urban planning in the city to contribute to reducing the damage, even with a simple thing, and to reduce the negative effects that the city experiences and strive to find determinants for development and improvement.

\section{HISTORICAL STAGES OF PALESTINIAN CITIES AND LAND-USE PLANNING}

Historical stages of Palestinian cities, especially last century history, greatly affected the land use:

1) The first stage: the stage of the Ottoman Empire 1517 AD-1917 AD.

2) The second stage: the period of the British Mandate 1917 AD-1948 AD.

3) The third stage: the annexation of the West Bank to Jordan, and the Gaza Strip to Egypt, 1948 AD-1967 AD.

4) The fourth stage: the stage of the Israeli occupation 1948 AD-1994 AD.

5) The fifth stage: the stage of the Palestinian Authority from 1994 to today.

These last phases had great impact on Hebron for its management and planning, as everyone who came to Palestine established laws for managing areas for his service and interest, and today we find that the Palestinian National Authority uses old laws or relies on them. Nowadays there are two different laws, one applied to the areas of the Israeli Civil Administration and other municipal laws in force in Palestinian cities [4].

Actually, the traditional Arab cities were not subject to prior plans in their manner, rather the formal and spatial formation of the urban fabric of this city was the result of man's understanding with the cultural and natural environment, based on experiences and practices, which gave the urban fabric its peculiarity and characteristics [5]. 


\section{THE IMPACT OF THE ISRAELI POLICY ON URBANIZATION IN THE WEST BANK}

From the beginning of the occupation, Israel has obstructed the natural growth of urban areas in Palestine trying to disconnect areas and residential communities.

Israel distributed its settlements on the outskirts of Palestinian cities and villages and established camps under the pretext of training and protection for settlers, and surrounding areas around the settlements as natural reserves for future expansion and future geographical contact. Israeli planners prepared local structural plans for Palestinians cities and villages to serve their own interests to occupy more Palestinian lands. In 1981, a 183 structural plan that doesn't even achieve the bare minimum of human needs for Palestinians was approved, even though it definitely was refused by Palestinians themselves [6]. Several years later, the Israeli Planning Central Department of the Military Administration prepared partial structural plans which aimed to narrow and limit Palestinian construction and urbanization for all Palestinians villages in the West Bank, which were approved at the beginning of 1994, after the signing of the Oslo Agreement in 1993. Unfortunately, a large number of these plans, which also promoted the increase of the settlements, are still valid now due to the absence of alternative or new structural plans [7]. These partial plans were prepared by Israeli planners using aerial photos and were limited to residential uses in streets that don't fulfill the needs of these villages, such as the width of the street (16 meters) inside the village, as well as not giving chances of future expansion for the existing residential buildings.

Whereas Israel is still implementing its racist plans by paving roads through Palestinian lands to serve its settlements, as well as demolishing nearby Palestinian houses and working to prevent expansion of Palestinian communities, as these communities surround the roads, their purpose was to stifle them and prevent them from expanding and even prevent landowners from approaching or entering their own lands. Under the rule of the ex-president of the United States Donald Trump, despite the fact that the signed agreements prevent settlement or any activity supporting it, there are still Israeli mechanisms to pave new roads to fulfil its intended plans at the expense of he lands of the Palestinians who are incapable of doing anything [8].

\section{THE OCCUPATION AND ITS IMPACT ON THE OLD CITY OF HEBRON}

Since the beginning of the occupation Israeli paved a road in the eastern side of the old city, destroying the main entrance to the Ibrahimi Mosque and many neighboring archaeological buildings in order to connect their settlement of Kiryat Arba, east of the city to the Ibrahimi Mosque, which is of special importance to Jewish, and to communicate with the Tel Rumeida area, a settlement outpost in a strategic location (Fig. 2) [9]. This occupation led to many residents leaving their houses and concentrating in old areas such as Haret al-Sheikh neighborhood and Bab al-Zawiya. Other residents built dwellings inside the spaces, squares, and orchards within the urban fabric of the old city center because these families did not have a place to shelter, so they occupied spaces that were formerly used as places for entertainment or green areas, such as Al-Sadaqah Garden (Fig. 3) [9].

So, the city stretched and expanded, but without planning, as many first built houses and then licensed it. Also, several historical buildings were removed and demolished, due to weak existing legislation and laws, to pave the new road or to build commercial buildings These buildings have no connection with the city's past in terms of cultural, architectural and heritage values nor does it even feature the Palestinian identity that it is supposed to protect. From our connection, our identity, our culture and the continuity of our existence, we must work on not eliminating and preserving them and spreading awareness among people of their importance [10]. 


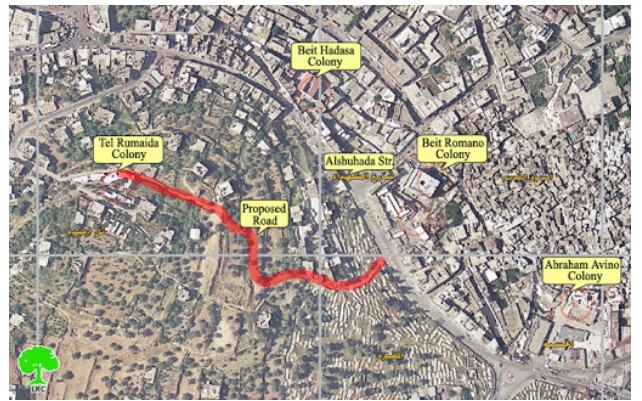

Figure 2: Tel Rumeida, suggested street for the settlement.

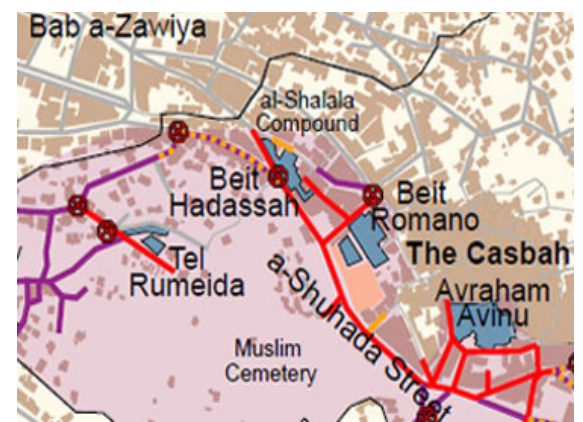

Figure 3: Israeli settelments in the old city.

\section{THE CURRENT URBAN EXPANSION IN THE CITY OF HEBRON}

Nowadays, Hebron expanded in various directions, but very strict restrictions are put by Israel, such as the confiscation of land, preventing construction and even the expansion or restoration of existing buildings. In some areas, construction materials are not allowed inside. Other than working on the displacement of the population, especially in the east and south of the city [10].

In the city center, Israel has built commercial residential units that have nothing to do with the urban fabric and its architectural character, along with the presence of the occupation forces stressing the lives of Palestinians in these areas in order to let them migrate from their houses.

The city lacks stability and political calmness due to these outposts that have been planted in the center, this resulted in moving the historical center to the adjacent northern side in "Bab Al-Zawiya" area, transforming it into the new commercial city center. Urbanization extended densely in this area and in other areas such as "Ain Sarah" (Fig. 4), "Al Salam" Street, "Ras Al-Joura", and others. However, the huge buildings were concentrated closely to "Bab Al-Zawiya" that has become a crowded area with underserved commercial markets. The city already suffers from the lack of street efficiency, which can be limited up to three main axes, starting from the northern entrance to the city, which is the area of "Ras al-Jura", to its southern new center, "Bab Al-Zawiya" (Fig. 5), including: Ain Sarah Street Namira Street, Al Salam Street and secondary streets branching from the previously mentioned streets [11].

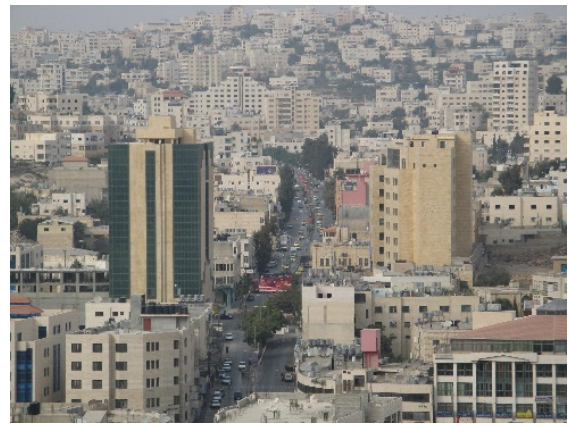

Figure 4: Ain Sarah Street "new buildings".

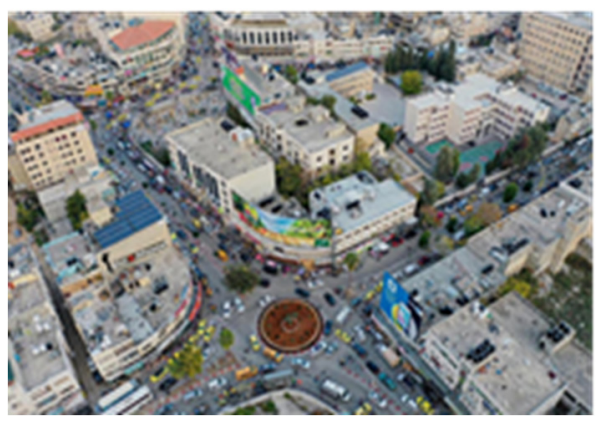

Figure 5: The new commercial district in Bab Al-Zawiya. 
The city contains public services like schools, universities, hospitals, small parks, internal and external transport networks, all of the existing services are definitely not enough for the city's population and it's expatriates, so there is a constant need to improve the living conditions of the population, which have become difficult in randomly distributed residential buildings along with the overlapping of residential with commercial and industrial buildings, and for the traffic congestion and parking spots in the middle of the streets, which has led to a complete chaos, due to non-compliance with the developed yet not certified plans [10]. Whoever has the possibility to build, does it randomly an arbitrarily without heading to the municipality's planning institutions to request a license.

Moreover, the abandonment of the old city center and its surroundings and the rapid moving out to other new areas has led to the emergence of a random, irregular and inconsistent structure without the bare minimum of services (Fig. 6). The presence of "AlAroub" camp in the north of the city and "Al-Fawwar" camp in its south adversely affect the performance and system of the city. The economic situation was already bad, and due to the emergence of the Coronavirus pandemic, it has become worse and the population has got poorer (Fig. 7).

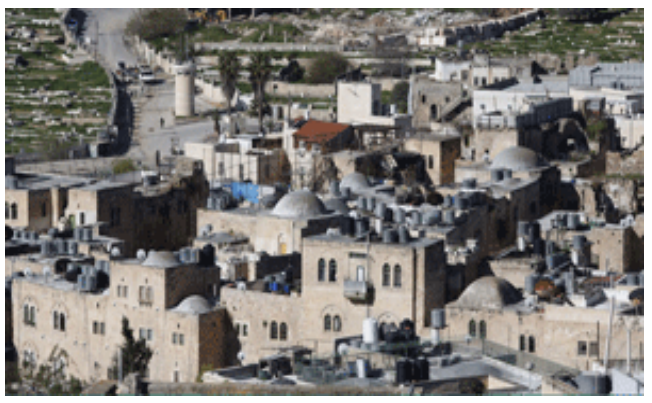

Figure 6: Israeli settlements, new buildings in the heart of Hebron.

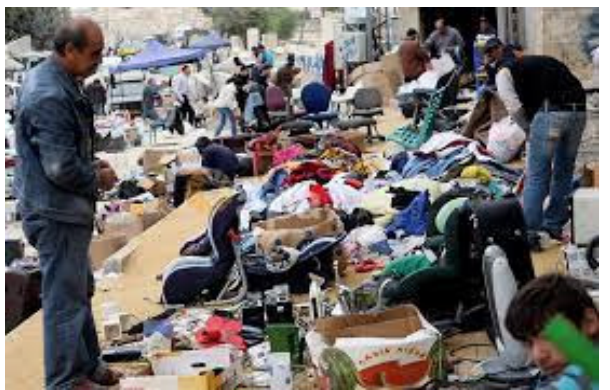

Figure 7: The bad economic situation in the city.

\section{PLANNING UNDER THE PALESTINIAN NATIONAL AUTHORITY}

The idea of summarizing the challenges and obstacles faced by the Palestinian National Authority with simple plain words is actually difficult due to the existing complex situation, especially that 27 years passed by and what was already agreed on between both Palestinian and Israeli sides is considered to be null, invalid and not even applicable specially from the Israeli side.

\subsection{Political challenges}

Related to administrative and security divisions and redeployment in various stages, causing geographical contiguity between the Palestinian areas [11].

\subsection{Geographical challenges and obstacles}

Considered what the Israeli occupation has done on the Palestinian lands, whether by the settlements that are still getting built and expanded, the bypass roads that connect these settlements, and the apartheid separation wall between the Palestinian areas in the West Bank and Jerusalem [9]. 


\subsection{Regulations challenges}

The Palestinian National Authority has made various attempts and efforts, especially the planning departments and its institutions, to regulate urban development and land use. The process of planning and organizing for all institutions in all Palestinian cities is still unable and incapable of solving the many problems that can be summarized as follows:

1. The lack of clear policies and laws in urban planning levels.

2. The lack of structural plans, laws and legislations. And even if it is found, it is not followed up and implemented as required.

3. Poor coordination and cooperation between institutions, lack of medical and administrative staff, and lack of experience.

4. Absence of land settlement and classifications, which leads to a lack of clarity about ownership. And weakness and lack of information, data, maps, etc.

5. Lack of funding to make such schemes, and the weakness of the private sector in terms of financing, and even that there is no popular and local participation.

6. Most of the Palestinian cities contain Palestinian refugee camps, as these camps are not subject to the laws and legislation enforcing the cities and villages of the West Bank. Which constitutes the phenomenon of random spread in the architecture [12].

7. In 2000, Israel reoccupied major cities and villages in the West Bank, which negatively affected municipalities and urban planning institutions.

\section{THE IMPACTS OF DIVIDING HEBRON CITY}

Before the beginning of 1997, Israel controlled all of the Hebron area. On January $17^{\text {th }}$, The Hebron Protocol was signed, concerning partial redeployment of Israeli military forces from the city. Under this agreement, Hebron was divided into two areas: $\mathrm{H} 1$ and $\mathrm{H} 2$. Control of H1 (80\%) shifted to the Palestinian Authority and H2 (20\%) remained under Israeli military control. The $\mathrm{H} 2$ area is inhabited by Palestinians and 500 settlers living in four downtown settlements inside the Old City. This area is under Israeli security control, with the exception of some civil powers of the Palestinian National Authority.

As Palestinians, we can be certain that the impact of this agreement on the city was disastrous in all areas, especially the economic aspect. It has negatively affected the urban planning and economic sector of the city, as well as the emotional impact of dividing the city into two parts, cutting off their social contact, in addition to the fact that there are no services for Palestinians as a result of the control of the Israeli army that protects the settlers (Fig. 8).

The main streets around the Area $\mathrm{H} 2$ were closed, such as: Al-Shuhada Street, which is the oldest street in the city and passes from its western side, and this closure actually divided the city into two parts (Fig. 9). Othman bin Affan Street, which is located on the eastern side, was also closed [9]. This street is considered as the main link between the north-east of the city and the south and is currently used only by settlers' vehicles between the Kiryat Arba settlement in the east of the city and its historical center, especially the Ibrahimi Mosque, as Palestinians are not allowed to use this street.

The results of that agreement were very bad and negative, as the residents of the Old City deserted their homes for settler attacks on them, poor economic conditions, lack of job opportunities and neglect of the area. This led to the concentration of criminality there, as a result of the lack of Palestinian authorities, in addition to the Israeli complicity with these people and even protect them, which made the area more isolated than it was [12]. 


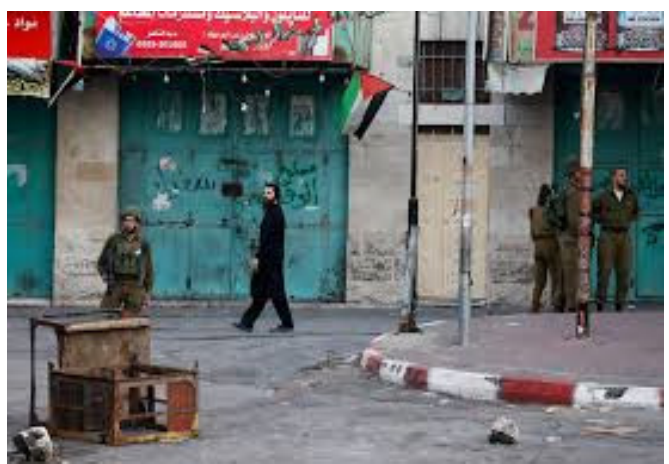

Figure 8: Settlers and soldiers in Shuhada Street.

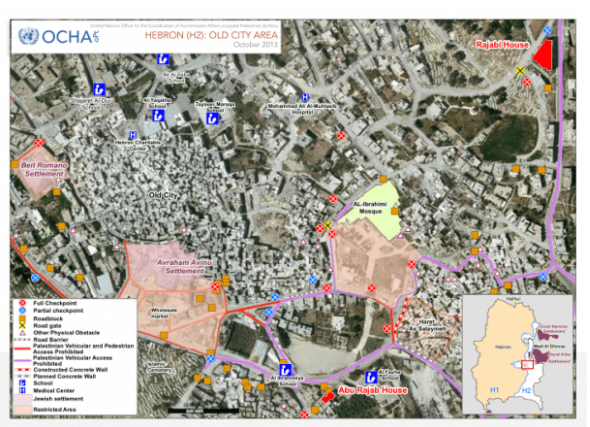

Figure 9: Hebron $\mathrm{H} 2$ old city area.

Nowadays, the citizens are demanding the PNA to cancel that agreement especially after seeing its negative results and effects on the economic aspects, which made the Palestinians unable to meet the needs and requirements of families and to provide a living for their children.

\section{PLANNING STRATEGIES FOR HEBRON GOVERNORATE}

Following the analysis of the different areas in the Hebron Governorate, standards, concepts and theories must be developed to help understanding the use of lands for the governorate in general and for the city in particular. In order to improve the physical, dynamic, social and economic environment. And making these studies feasible with the correct use of the multiple spaces of land, whether it is internal, external, agricultural, industrial, commercial, or residential lands.

It is also necessary to work on creating and improving the infrastructure, improving the internal transportation network, avoiding the depletion of resources, and developing programs and strategies for the continuity of work on the concepts of sustainability, side by side with the competent authorities, the government and local people as well. Land use must be re-studied and its planning and systems must be re-programmed as well according to the new sites of the Palestinian lands [11].

\section{FACTORS AFFECTING PLANNING IN HEBRON CITY}

1. The presence of settlements and outposts around the city and in its center.

2. Weak city administration due to the Israeli occupation.

3. The lack of application of structural plans and wrong distribution of land use.

4. Weak and old laws and legislations.

5. The political division of the city according to the 1997 Hebron Agreement, known as the Paris agreement.

6. Weak human and material resources and lack of attracting talents.

7. Israeli closures and checkpoints in the city.

8. Narrowing the city by bypassing highways and limiting its natural expansion.

9. Lack of awareness and lack of educating citizens about the value of the historical and cultural heritage.

10. Poverty and bad economic situation. 


\section{THE PROMINENT PROBLEM IN THE CITY OF HEBRON: STREET VENDORS}

Nowadays, due to unemployment and economic crisis the problem of street vendors in the city represents a cultural, local, economic and social disaster. The street vendor is a mobile or fixed point of sale by groups of toiling classes of the people who sell some products of all kinds to make money. Hand drawn vehicles are used in densely populated areas, while for distant neighborhoods they use a cart pulled by the wheel.

Usually, vital sites are chosen or at intersections in the city center, where there are at least 300 street vendors, most of them selling vegetables, fruits, clothes, juices, ice cream, etc.

More than 3 years ago, the Hebron municipality allocated a site for vendors: a covered market located in the city center, near Bab Al-Zawiya with public toilets, a guard room and opened a special street for it that it cut from the playground of the Muhammadiyah School despite the presence of two wide entrances and another on foot. Unfortunately, the market did not work as planned; Vendors have again spread out along the main streets near this market.

These sellers are illegal and so they do not have a license, apart from creating other problems which can be summarized as follows:

1. Obstructing traffic for vehicles and pedestrians;

2. Environmental problems as these vendors leave residues of waste and others;

3. The problem of noise and inconvenience promoting their goods;

4. Social problems caused by sellers' quarrels with each other;

5. Violating the sidewalks and sometimes the street itself, without caring about bystanders or drivers;

6. Indifference to the responsible authorities, instructions and legal texts, refusal to pay violations, and indifference to confiscation of goods and others; and

7. Different prices between the licensed shop and the non-tax-paying vendors.

\subsection{Challenges and obstacles}

Local authorities find it difficult to solve problems with rover owners due to the difficulty of the mentality of these people who feel to be above the law and have nothing to lose. Many of these salesmen are part of strong and influential family, which is an obstacle for the competent authorities. The large number of street vendors led the municipality to restrict them to one place or even find a suitable place to be accepted by the sellers.

Because of cheap prices, crowds of people arrive to buy, especially on Saturday, Sunday and Tuesday or holidays, where the demand for clothes, food commodities and children's toys increases.

Consequently, there are problems of traffic congestion, especially during the month of Ramadan in old Wadi al-Tuffah Street, the new Wadi al-Tuffah and the Bab al-Zawiya area as well as noise and suffering.

The Coronavirus pandemic came more than a year ago, and it has made life even more difficult than it was, so quick and economic solutions have become urgent because institutions in West Bank in general, especially municipalities, even though are aware of the poverty problem of these street vendors, they turn a blind eye most of the time [1]. 
10.2 Hebron municipality initiatives to solve the problem of these vendors

\subsubsection{First: Arab Bank land and ESSO gas station}

The Hebron municipality sought to solve the problem in the city, as it chose a plot of land at the gates of the northern old town near the Arab Bank and carried out a survey for street vendors and set up a program on the basis of creating a market that serves all sellers of various commodities and products, for example, vegetable carts come on Friday and Saturday, clothes carts take on Sunday, Monday, etc. (Figs 10 and 11).

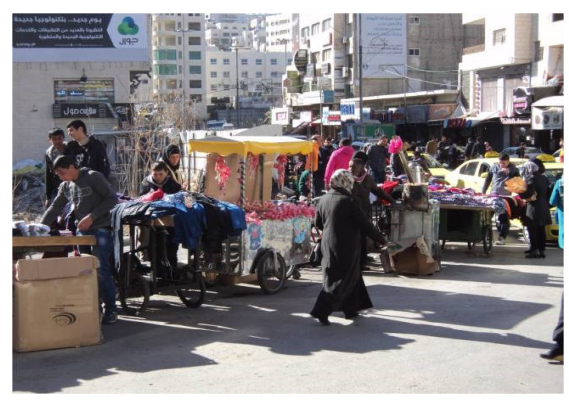

Figure 10: The fruit and vegetables market.

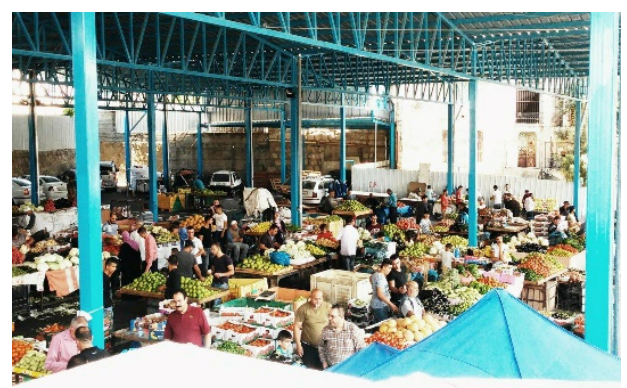

Figure 11: Peddlers in the street of Hebron.

The proposed land was planned and divided into a number of subdivisions, then counted and given the numbers of the specified locations, and a nominal fee was imposed for use in exchange for municipal services, Unfortunately, the project failed due to the refusal of the vehicle owners to move to the place for the following reasons:

1. After the proposed plot of land from the vital commercial center of the city.

2. Transferring the transportation line to feed the villages east and north of Hebron from the proposed location to the new car complex, which negatively affected the proposed area due to the lack of access to and abandonment of people to that area.

3. The car owners completely depend on their stalls to support their families daily, while the municipality wastes only two days of the work week.

The municipality, based on the vehicle owner's request, searched for a closer place that matches the arguments of the vehicle owners' demands, and found land near the city's commercial center.

\subsubsection{Second: The land of Dais}

The municipality re-classified the statistical classification of the owners of vehicles who relied only on it to support their families as a main source of income and found that the real percentage of vehicles was only $60 \%$ of the total existing vehicles, since some of them owned and rented more than one vehicle.

The municipality studied the project for the plot of land that was more capable than the owners of the vehicles, but the project stumbled and was not implemented, since the proposed land is private land and not government in a very vital location where no agreement was reached between the two parties (the owner and the municipality). 
We find that the carriage problem has stumbled, a solution to this day due to the lack of available lands and the lack of compliance by the sellers with the law. Therefore, another area must be studied, even if it is far away, and institutions should be placed next to it that help in the activity of movement in it, as Jordan has done the popular market in the Ras AlAin area in central Amman near bus stations the main market is considered successful.

\section{CONCLUSIONS AND RECOMMENDATIONS}

Urban planning is the formation of a physical environment in line with the requirements, needs and behaviors of its users, therefore we find that the urban spaces that prevent the requirements of the users lead to negative behaviors that may be environmental, behavioral, economic, social or cultural. Therefore, this will affect by following other methods such as abandoning the area or making another arrangement or modification and addition to this urban area to match their requirements and behaviors, or individuals acquiring new behaviors to adapt to those spaces, which leads to deformation and loss of the physical environment.

The city's regulations, antiquity and modernity created imbalance and homogeneity in the urban space, whether in terms of form or function. Therefore, the research reached the following convictions and results:

1) The absence or non-adoption and approval of the structural plan in the city of Hebron, whose importance lies in controlling the quality and efficiency of the visual image of the urban landscape, controlling land use and building heights, and working on providing services, will lead to more negatives and complications that affect Urbanism, the environment, people's behavior, and more suffering and poverty.

2) The need to accelerate the review of the unapproved structural plan and put it to the specialists, satisfy the needs of the city and the citizens, and issue a plan that meets the population needs and the comprehensive development of the city.

3) The necessity of drafting new laws to work on the city in accordance with the law and urban and building requirements.

4) Resorting to international and human rights institutions to inform them of the racism that Israel does towards the Palestinian people and their land.

5) The necessity to allocate funds to make plans and to implement development projects, especially infrastructure and road networks, and to support local authorities and institutions and develop their cadres to enable them to work and implement these plans.

6) Confronting, by all means and capabilities, the Israelis who keep sabotaging the city of Hebron by means of settlements, bypass roads, and outposts, where the political situation plays a major role in the urban structure, its expansion and spread.

\section{REFERENCES}

[1] Chamber of Commerce and Industry of Hebron. 2017 (Arabic).

[2] Palestinian Central Bureau of Statistics. p. 29, 2010 (Arab).

[3] https://www.progettodreyfus.com/gli-accordi-di-oslo-il-testo-integrale/.

[4] Al-Kanani Camel, K.B., Arab Islamic Town Planning, p. 6, 2006.

[5] A sequence of Palestinian history since the First World War. https://www.bbc.com/ arabic/40739743. Accessed on: 10 Apr. 2021.

[6] Applied Research Institute Jerusalem-Arij-pp.7-11-13, 2009.

[7] Isleimieh Mahmoud, A.M., Israeli colonies impact on physical expansion of Palestinian Settlement Hebron Governorate. Master thesis degree, unpublished test, pp. 69-74, 2006 (Arabic). 
[8] Palestine Ministry of Local Government. https:/geomolg.ps/L5/index.html? viewer=A3.V1. Accessed on: 15 Apr. 2021. Hebron (H2) - Old City Area (October 2013).

[9] Al-Tafkaji Khalil, Israeli Settlements in the West Bank, Palestinian Geographical Center, Jerusalem, Palestine, 1994 (Arabic).

[10] Abu Serrieh, A.H., Urban design. Unpublished test, Palestine Polytechnic University, p. 53, 2019.

[11] Hebron-Architecture-Urban Planning-ar.wikipedia.org. Accessed on: 10 Apr. 2021.

[12] Vv.Aa., Hebron Ancient Charm of the City and Historical Architecture, the first edition, Hebron Rehabilitation Committee: Palestine, 2008 (Arabic). 